\begin{tabular}{c} 
Brazilian Journal \\
of Chemical \\
Engineering \\
\hline
\end{tabular}

ISSN 0104-6632

Printed in Brazil

www.abeq.org.br/bjche

Vol. 30, No. 03, pp. 477 - 486, July - September, 2013

\title{
PINEAPPLE FRUIT BROMELAIN RECOVERY USING RECYCLABLE FUNCTIONALIZED ORDERED MESOPOROUS SILICA SYNTHESIZED FROM SUGARCANE LEAF ASH
}

\author{
A. Arumugam* and V. Ponnusami \\ School of Chemical \& Biotechnology, SASTRA University, Phone: + 914362 264101, Thanjavur, India. \\ E-mail: aruchemx1@scbt.sastra.edu
}

(Submitted: February 28, 2012 ; Revised: August 15, 2012 ; Accepted: September 5, 2012)

\begin{abstract}
Bromelain, a protease enzyme found in Ananas comosus (Pineapple), was recovered from the fruit juice by adsorption using recyclable functionalized Santa Barbara Acid-15 (SBA-15) synthesized from sugarcane leaf ash. In this work, highly ordered mesoporous silica was synthesized from sugarcane leaf ash by a template-assisted method. It was successfully used as an adsorbent for the recovery of bromelain from pineapple fruit pulp. Amine-functionalized mesoporous silica exhibited a recovery efficiency of $97.89 \%$ and a 6.2-fold purification. It was also established that the adsorbent could be easily regenerated by adjusting the $\mathrm{pH}$. In this study, the adsorbent was reused for three cycles without noticeable loss in recovery efficiency. Thus, adsroption using functionalized SBA-15 appears to be a promising alternate separation technique for the recovery of fruit bromelain.

Keywords: Bromelain; Mesoporous silica; Adsorption.
\end{abstract}

\section{INTRODUCTION}

Bromelain is a protease enzyme, a class of enzymes that catalyze the hydrolysis of the peptide bonds of proteins, which eventually leads to the breakdown of the protein. Bromelain is a collective name for all proteases, sulfhydryl proteolytic enzymes belonging to the Bromeliaceae family. Fruit bromelain has several applications in medicine, pharmacology, and food industries (Maurer et al., 2001).

The enzymatic activity of bromelain greatly depends on its biochemical and pharmacological properties. Considering its end applications, bromelain must be highly pure. As the physical properties of major proteins are similar and protein concentration in the fermentation broth is low, it is very difficult and expensive to recover the desired enzyme from the broth. Thus, the recovery process of targeted proteins is of major interest to the biotechnological industries (Hale et al., 2005).

Frequently used methods for the recovery of bromelain are aqueous two-phase extraction (Ferreira et al., 2011), salt precipitation (Hebbar et al., 2010) and membrane separation (Hebbar et al., 2010). These processes are, however, either inefficient or expensive. Song et al. (2011) recently reported the recovery of bromelain by affinity adsorption using reactive red 120 immobilized magnetic composite particles. Ion exchange chromatography was used by Devakate et al. (2009). Hebbar et al. (2010) studied the separation and purification of bromelain by reverse micellar extraction and ultrafiltration.

In this work, bromelain was purified from pineapple fruit by adsorption using functionalized SBA-15 synthesised from sugarcane leaf ash, a low cost silica precursor. The functionalised SBA-15 obtained from sugarcane leaf ash shows large surface area. The regular repeating pore structures of these

*To whom correspondence should be addressed 
materials facilitate adsorption or entrapment of large molecules within their pores.

Mesoporous particles tend to form stable reusable chromatographic columns because of their mechanical and chemical stability. These columns can be operated under high pressure and flow rates (Park et al., 2009).

In the literature, several methods for SBA-15 synthesis have been reported using a range of silica precursors, including tetra-alkoxysilane, fumed silica, water glass and sodium silicate (Meynen et al., 2009). The major drawback is that these precursors are expensive and also toxic. Thus, an alternate silica source obtained from sugarcane leaf ash appears to be a promising option (Halina et al., 2009).

\section{MATERIALS AND METHODS}

The production of mesoporous silica involves the use of sugarcane leaf ash as the silica precursor. The sugarcane leaf ash was obtained from a nearby sugar industry. Polyethylene glycol-polypropylene glycolpolyethylene glycol [Pluronic P123], a triblock copolymer, $\left(\mathrm{PEO}_{20} \mathrm{PPO}_{70} \mathrm{PEO}_{20}\right)$ was used as a template. The alkoxysilanes selected for the functionalization process were phenyltriethoxysilane $(\mathrm{EtO})_{3} \mathrm{Si}-\mathrm{Ph}$, (98\%, Aldrich), 3-aminopropyltriethoxysilane (EtO) ${ }_{3} \mathrm{Si}-$ $\mathrm{PrNH}_{2}$, (98\%, Aldrich), mercaptotriethoxysilane, (EtO) $)_{3} \mathrm{Si}-\mathrm{PrSH},(95 \%$, Avocado) and 4-(triethoxysilyl) butyronitrile (EtO) $)_{3} \mathrm{Si}-\mathrm{PrCN},(98 \%$, Aldrich). These reagents were purchased from Aldrich and used without further purification. Potassium dihydrogen phosphate, dipotassium hydrogen phosphate, copper sulphate pentahydrate, casein, sodium potassium tartarate, trichloroacetic acid, and sodium carbonate were obtained from Himedia Laboratories Pvt Ltd. Tyrosine was purchased from Sigma-Aldrich Pvt Ltd. Toluene was purchased from Qualigens Fine Chemicals Pvt Ltd. Folin's Ciocalteau Reagent, trimethylbenzene, and hydrochloric acid were obtained from Merck Chemicals Pvt Ltd.

\section{Sample Preparation}

Fresh pineapple fruit was taken; the stem and the peel portions were removed. The pulp portion was crushed well using a mortar and pestle and then centrifuged at $4{ }^{\circ} \mathrm{C}$ at a speed of $10,000 \mathrm{rpm}$ for 20 minutes to remove the debris. The supernatant obtained was filtered with Whatman number 01 filter paper and the filtrate was used for further studies.

\section{Preparation of Mesoporous Silica}

The X-Ray Fluorescence (XRF) analysis of ash is given in Table $1.1 \mathrm{~g}$ of finely ground ash was fused with sodium hydroxide in the ratio of $1: 1.2$ at a temperature of $450{ }^{\circ} \mathrm{C}$ for 1 hour. The fused mass was diluted with water in the ratio of 1:4 followed by sonication to completely disperse the particles. The solution was then filtered repeatedly until a colourless filtrate was obtained. This sodium silicate solution (water glass) is a viscous, transparent, colourless solution. Being an inexpensive silica source obtained from sugarcane leaf ash, it was used as a precursor for the synthesis of mesoporous SBA-15 (Zhao et al., 1998).

5 g P123 triblock copolymer was added to an acidified solution prepared by dissolving $1 \mathrm{~g}$ of $1 \mathrm{~N}$ $\mathrm{HCl}$ in $43.2 \mathrm{~g}$ of demineralized water and stirred for $1 \mathrm{~h}$ at $35^{\circ} \mathrm{C}$ until a homogeneous solution was obtained (Gandhi et al., 2001). Then 12 g sodium silicate obtained from sugar cane leaf ash was added and stirred at $35^{\circ} \mathrm{C}$ for $24 \mathrm{~h}$. The solution was then transferred to a Teflon bottle and aged for $72 \mathrm{~h}$ at $120{ }^{\circ} \mathrm{C}$ to obtain SBA-15. The solid products were filtered and washed repeatedly with DI water, dried at room temperature for $24 \mathrm{~h}$ and then calcined for $8 \mathrm{~h}$ at $550{ }^{\circ} \mathrm{C}$ in air (Meynen et al., 2009).

Table 1: XRF results for elements in their oxide form in sugarcane leaf ash.

\begin{tabular}{|c|c|}
\hline Formula & Concentration (Wt \%) \\
\hline $\mathrm{SiO}_{2}$ & 80.14 \\
$\mathrm{CaO}$ & 6.06 \\
$\mathrm{MgO}$ & 5.02 \\
$\mathrm{~K}_{2} \mathrm{O}$ & 3.09 \\
$\mathrm{SO}_{3}$ & 2.25 \\
$\mathrm{Al}_{2} \mathrm{O}_{3}$ & 0.89 \\
$\mathrm{Cl}_{\mathrm{Fe}_{2} \mathrm{O}_{3}}$ & 0.67 \\
$\mathrm{Na}_{2} \mathrm{O}$ & 0.51 \\
$\mathrm{MnO}$ & 0.28 \\
$\mathrm{TiO}_{2}$ & 0.17 \\
$\mathrm{CuO}$ & 0.046 \\
\hline
\end{tabular}




\section{Functionalization of Mesoporous Silica}

Bare mesoporous SBA-15 was functionalized for enhancement of the properties of the siliceous surface. Functionalization was performed (post synthesis) using tri-ethoxy propyl silane compounds with suitable groups, these groups being tethered onto the inner wall surface of silica particles (Hwang et al., 2010). Here, toluene was used as the medium in which functionalization occured. $125 \mathrm{~mL}$ of anhydrous toluene along with $3.75 \mathrm{~g} \mathrm{SBA}-15$ and $4.68 \mathrm{~mL}$ of the tri-ethoxy propyl silane compound with the desired functional group were mixed together. The mixture was refluxed for $24 \mathrm{~h}$ and the functionalized mesoporous particles thus obtained were washed 5 times with toluene to remove loosely bound ligands. Thus, the required functional group was tethered onto the inner surface of the silica by propyl chains, liberating ethanol (Aguado et al., 2009).

\section{Activity Assay of Bromelain}

The proteolytic activity of bromelain was measured by the casein method. $1 \mathrm{ml}$ Protease sample was taken in a test tube and $5 \mathrm{ml}$ of casein was added and allowed to stand for 10 minutes at room temperature. Then $5 \mathrm{ml}$ of TCA was added and allowed to stand for 30 minutes in room temperature. The sample was then filtered twice using filter paper and $2 \mathrm{ml}$ of the solution was taken. Then $5 \mathrm{ml}$ of sodium carbonate and $1 \mathrm{ml}$ of Folin-Ciocalteau reagent were added and allowed to stand for 30 minutes and absorbance was noted at $660 \mathrm{~nm}$.

$$
\begin{aligned}
& \text { ( } \mu \text { mole Tyrosine equivalents } \\
& \text { released) } \\
& \operatorname{Enzyme}(\mathrm{U} / \mathrm{ml})=\frac{\times(\text { Total volume of assay })}{(\text { Volume of enzyme used })}(1)
\end{aligned}
$$

The bromelain recovery (\%) and purification (fold) were estimated as shown below:

$$
\text { Bromelain recovery }(\%)=\frac{\begin{array}{c}
\text { bromela in } \\
\text { recoverd }(\mathrm{mg} / \mathrm{L})
\end{array}}{\begin{array}{c}
\text { bromelain in } \\
\text { the feed }(\mathrm{mg} / \mathrm{L})
\end{array}} \times 100
$$

Specific activtity of

$$
\text { Purification }(\text { fold })=\frac{\begin{array}{c}
\text { Specific activtity of } \\
\text { bromelain after recovery }
\end{array}}{\begin{array}{c}
\text { Specific activity of } \\
\text { bromelain in the feed }
\end{array}}
$$

\section{Bromelain Recovery by Adsorption}

$50 \mathrm{~mL}$ of crude extract was mixed with $50 \mathrm{~mL}$ of deionized water. Then $0.1 \mathrm{~g}$ of functionalized mesoporous silica was added to the solution. The mixture was kept in an orbital shaker at $120 \mathrm{rpm}$ and room temperature. Samples were taken at regular time intervals, filtered and the filtrate was assayed for bromelain and total protein content. Sampling was carried out until equilibrium was attained. Protein content and bromelain activity were determined by the Lowry and Casein methods, respectively.

The amount of bromelain adsorbed per unit mass of the adsorbent at equilibrium $\left(\mathrm{q}_{\mathrm{e}}, \mathrm{mg} / \mathrm{g}\right)$ was calculated using the following expression (Piccin et al., 2011):

$\mathrm{q}_{\mathrm{e}}=\frac{\left(\mathrm{C}_{\mathrm{o}}-\mathrm{C}_{\mathrm{e}}\right)}{\mathrm{m}}$

where $\mathrm{C}_{\mathrm{o}}$ and $\mathrm{C}_{\mathrm{e}}$ are the initial and equilibrium bromelain concentrations in $\mathrm{mg} / \mathrm{dm}^{3}$ and $\mathrm{m}$ is the amount of particles required in $\mathrm{g} / \mathrm{dm}^{3}$.

\section{Equilibrium Analysis}

Equilibrium data were analyzed with the most popularly used Langmuir and Freundlich isotherms models. These models are given by the following equations (Senthil Kumar et al., 2010):

Langmuir isotherm:

$$
\mathrm{q}_{\mathrm{e}}=\mathrm{q}_{\mathrm{m}} \frac{\mathrm{K}_{\mathrm{L}} \mathrm{C}_{\mathrm{e}}}{1+\mathrm{K}_{\mathrm{L}} \mathrm{C}_{\mathrm{e}}}
$$

Freundlich isotherm:

$$
\mathrm{q}_{\mathrm{e}}=\mathrm{K}_{\mathrm{F}} \mathrm{C}_{\mathrm{e}}^{1 / \mathrm{n}}
$$

where $\mathrm{q}_{\mathrm{e}}, \mathrm{q}_{\mathrm{m}}$, and $\mathrm{K}_{\mathrm{L}}$ stand for the equilibrium solid phase concentration $(\mathrm{mg} / \mathrm{g})$, Langmuir monolayer adsorption capacity $(\mathrm{mg} / \mathrm{g})$, and Langmuir equilibrium constant $\left(\mathrm{dm}^{3} / \mathrm{mg}\right)$, respectively. $\mathrm{K}_{\mathrm{F}}$ and $\mathrm{n}$, the Freundlich isotherm parameters, are indicators of adsorption capacity and adsorption intensity, respectively. While the Langmuir isotherm is applicable for homogenous surface adsorption, the Freundlich model is used for heterogeneous surface. 


\section{Regeneration of SBA-15}

One of the important aspects of choosing an adsorbent is the ease of regeneration. To assess desorption of bromelain from the mesoporous adsorbent, the bromelain-laden adsorbent was re-suspended in $50 \mathrm{~mL}$ of Tris- $\mathrm{HCl}$ buffer solution at $\mathrm{pH} 10$. The mixture was stirred for $2 \mathrm{~h}$, and then centrifuged and the supernatant assayed for protease to determine the amount of bromelain desorbed. The regenerated adsorbent was reused for bromelain recovery.

\section{Characterization of Functionalized Mesoporous Silica}

The presence of various functional groups in the functionalized mesoporous silica was confirmed by Fourier Transform Infrared Spectroscopy (Spectrum 100, Perkin Elmer, USA) in $\mathrm{HBr}$ pellets. The surface topography and morphology of the mesoporous materials were studied using a Scanning Electron Microscope (6701 F, JEOL, Japan). The volume and surface area of mesopores and BET surface area of the samples were determined by the $\mathrm{N}_{2}$ gas adsorption technique at $-195.79^{\circ} \mathrm{C}$.

\section{RESULT AND DISCUSSION}

\section{Characterization of Mesoporous Silica}

From SEM images shown in Fig. 1(a) and Fig. 1(b), it can be seen that SBA-15 has a typical wheat-like morphology and consists of aggregates of uniform rope-like particles. The FTIR spectrum is shown in Fig. 2 . The characteristic peak observed at $1082.78 \mathrm{~cm}^{-1}$ in the FTIR confirms the presence of hydroxyl

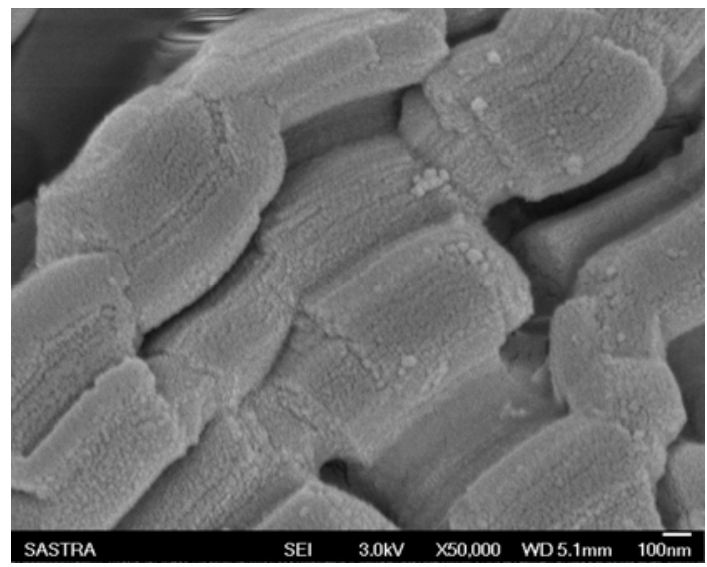

(a) groups in the bare SBA-15. The peak observed at $1083.71 \mathrm{~cm}^{-1}$ confirms the presence of the Si-O-Si group in all the bare and functionalized samples. The peak for a carboxylic group was observed at $1641.71 \mathrm{~cm}^{-1}$ in $-\mathrm{COOH}$ functionalized SBA-15. A peak at $1569.11 \mathrm{~cm}^{-1}$ and another peak at $3392.14 \mathrm{~cm}^{-1}$ confirm the presence of amine groups in aminefunctionalized SBA-15 (Nguyen et al., 2008). The peak at $1643.30 \mathrm{~cm}^{-1}$ confirms the presence of an aromatic ring stretch of the phenyl group. The aromatic planar stretch of phenyl was observed at $804.32 \mathrm{~cm}^{-1}$ (Bois et al., 2003). Thus, the sample confirms the presence of a thiol group (Chen et al., 2010).

The BET surface area was determined to be $573.95 \mathrm{~m}^{2} \mathrm{~g}^{-1}$ which was significantly larger than that of many natural materials. Pore size distribution was determined by applying the Barrett-Joyner-Halenda model $(\mathrm{BJH})$, assuming a cylindrical pore geometry. The average pore volume was estimated to be 0.838 $\mathrm{cm}^{3} \mathrm{~g}^{-1}$. Total pore volume was taken at a relative pressure $\mathrm{p} / \mathrm{p}_{0}$ of 0.9934 . Average pore diameter was found to be $6.61 \mathrm{~nm}$. Table 2 gives a comparison of the surface area, pore volume and pore diameter of SBA-15 synthesized from various sources.

\section{Effect of pH on Adsorption of Bromelain}

The effect of $\mathrm{pH}$ on the adsorption of bromelain is shown in Fig. 3. The optimum $\mathrm{pH}$ was found to be 5-7. The effect of $\mathrm{pH}$ can be explained considering the surface charge on the adsorbent material. At low $\mathrm{pH}$, due to the high positive charge density, electrostatic repulsion will be high, resulting in lower uptake of positively charged bromelain. The isoelectric point of bromelain is 9.55 (Wharton, 1974), hence the adsorption decreases at a higher $\mathrm{pH}_{\mathrm{i}}$.

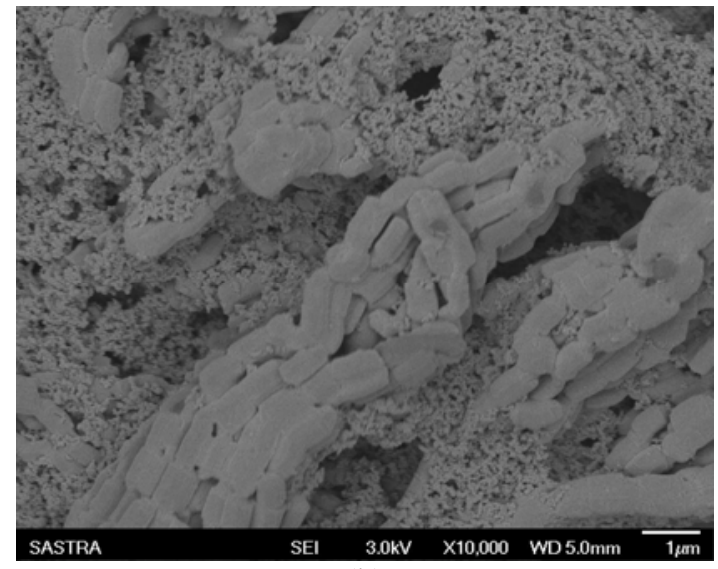

(b)

Figure 1: SEM image of SBA-15. 


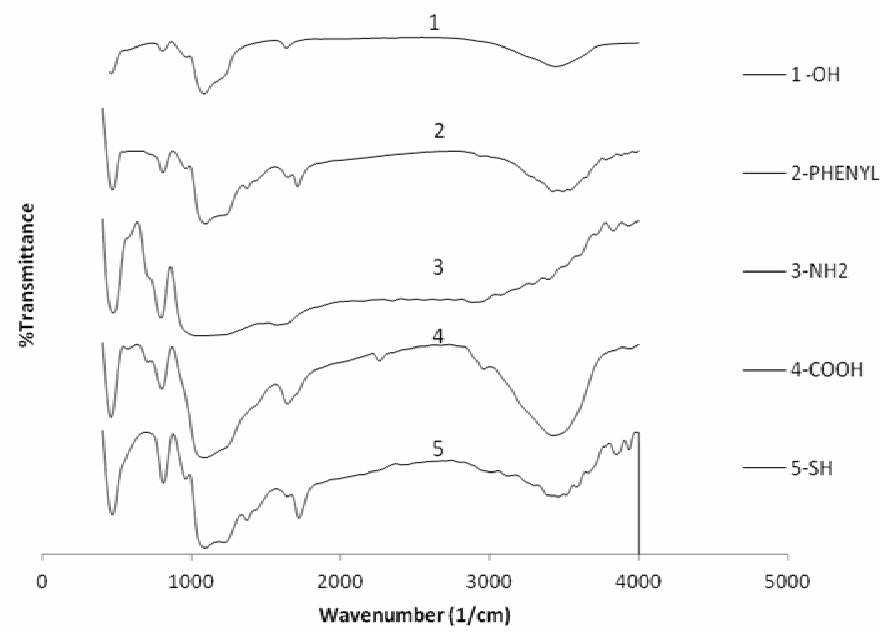

Figure 2: FTIR spectra of bare and functionalized SBA-15 mesoporous material.

Table 2: Surface area, pore volume and pore diameter of the mesoporous materials

\begin{tabular}{|l|c|c|c|}
\hline \multicolumn{1}{|c|}{ Sample } & $\begin{array}{c}\text { Specific } \\
\text { surface } \mathbf{a r e a} \\
\left(\mathbf{m}^{\mathbf{2}} \mathbf{g}^{-\mathbf{1}}\right)\end{array}$ & $\begin{array}{c}\text { Pore } \\
\text { volume } \\
\left(\mathbf{m L ~} \mathbf{~} \mathbf{- 1}^{\mathbf{1}}\right)\end{array}$ & $\begin{array}{c}\text { Pore } \\
\text { diameter } \\
(\mathbf{n m})\end{array}$ \\
\hline Present work & 574 & 0.838 & 6.61 \\
Aguado et al., 2009 & 790 & 1.44 & 9.1 \\
Kokunesoski et al., 2009 & 710 & 0.11 & 2.9 \\
Gandhi et al., 2011 & 645 & 0.85 & 6.1 \\
Jo et al., 2009 & 571 & 0.85 & 7.9 \\
\hline
\end{tabular}

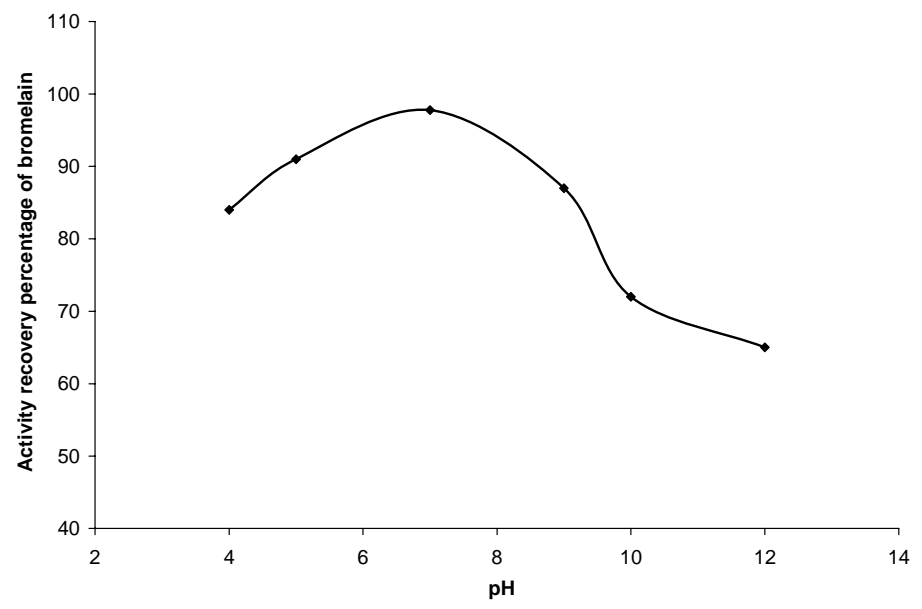

Figure 3: Effect of $\mathrm{pH}$ on the activity recovery percentage of bromelain. 


\section{Bromelain Recovery by Adsorption}

The adsorption capacities of SBA-15 with various functional groups synthesised in this work were compared. The maximum adsorption capacity of $0.813 \mathrm{mg} \mathrm{g}^{-1}$ was obtained for amine-functionalized SBA-15. Protein adsorbed onto functionalized SBA15 was eluted with Tris- $\mathrm{HCl}$ buffer solution at $\mathrm{pH} 10$ as mentioned in section 2.5. When the eluted solution was passed through gel-filtration chromatography, there was only one peak, which confirmed the presence of a single protein. FT-IR and SDS-Page confirmed that the protein recovered was bromelain. The amount of bromelain recovered was determined to be $97.89 \%$ using Eq. (2). Adsorption capacities of the other functionalized SBA-15 synthesized in this work were: bare SBA-15: $0.428 \mathrm{mg} \mathrm{g}^{-1}$; $\mathrm{COOH}-$ functionalized porous silica: $0.557 \mathrm{mg} \mathrm{g}^{-1}$; thiolfunctionalized SBA-15: $0.366 \mathrm{mg} \mathrm{g}^{-1}$ and phenylfunctionalized SBA-15: $0.555 \mathrm{mg} \mathrm{g}^{-1}$. The corresponding percentage recoveries were determined to be $68.47 \%, 85.99 \%, 53.59 \%$ and $84.06 \%$, respectively. Figure 4 gives the comparison of the kinetics of bromelain adsorption on the various functionalized SBA-15 mentioned above.

A purification of 6.2-fold (Ravindra Babu et al., 2008) was obtained in this work with the aminefunctionalised SBA-15. Ravindra Babu et al. (2008) employed aqueous two-phase extraction for the separation and purification of bromelain from pineapple and reported a 4.0-fold increase in purity. Devakate et al. (2009) used chromatography for bromelain purification and their results indicated that the enzyme purity obtained by ion exchange chromatography was 10 -fold and by precipitation 2.3-fold. Hebbar et al (2010) employed a reverse micellar system of the cationic surfactant cetyltrimethylammoniumbromide/isooctane/hexanol/ butanol used for an activity recovery of $95.8 \%$ and a purification of 5.9-fold. The purification of bromelain increased to 8.9-fold after ultrafiltration. Thus, compared to the purification techniques used traditionally, adsorption provides better separation, increased purity and has higher capacity and, therefore, reduces the cost, time and labour.

\section{Equilibrium Studies}

The Langmuir model described the system better than the Freundlich model (Fig. 5) (Vijayaraghavan et al., 2004). The Langmuir and Freundlich isotherm parameters determined by the least square method are given in Table 3.

\section{Fourier Transform Infrared Spectroscopy of Purified Bromelain}

The FTIR spectrum of freeze-dried bromelain is shown in Figure 6. The characteristic $\mathrm{C}-\mathrm{N}$ stretch vibration frequencies of monoalkyl guanidinium are assigned to the observed IR bands at 1638, 14251256 and $1053 \mathrm{~cm}^{-1}$. The band at $1760-1670 \mathrm{~cm}^{-1}$ (s) shows the presence of $\mathrm{C}=\mathrm{O}$ groups (amides at $\sim 1639 \mathrm{~cm}^{-1}$ ). This confirms the presence of amino acids that contain amine groups in their side chain, i.e., aspargine and glutamine (Devakate et al., 2009). Bands at $3428 \mathrm{~cm}^{-1}$ for -valine are assigned to the $\mathrm{N}-\mathrm{H}$ stretching mode.

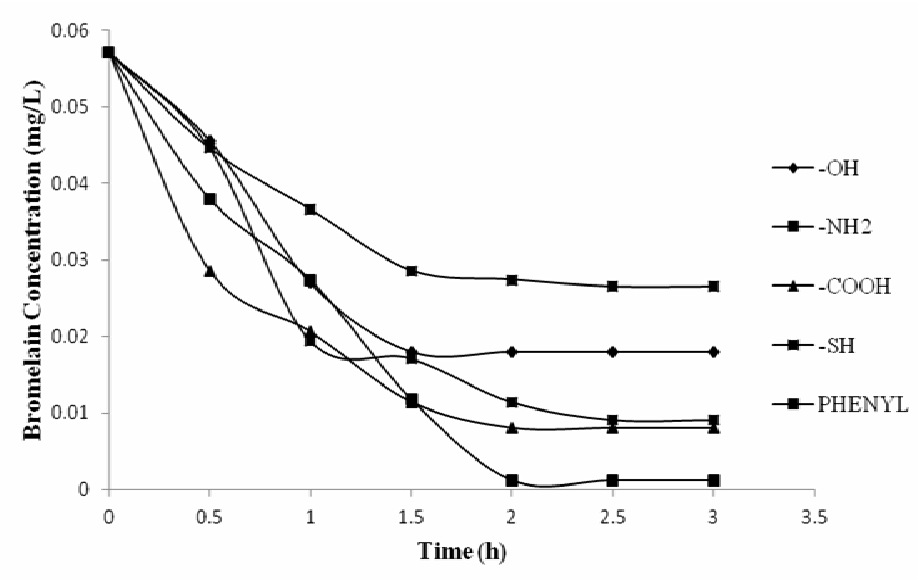

Figure 4: Bromelain adsorption on bare and functionalized SBA-15. 


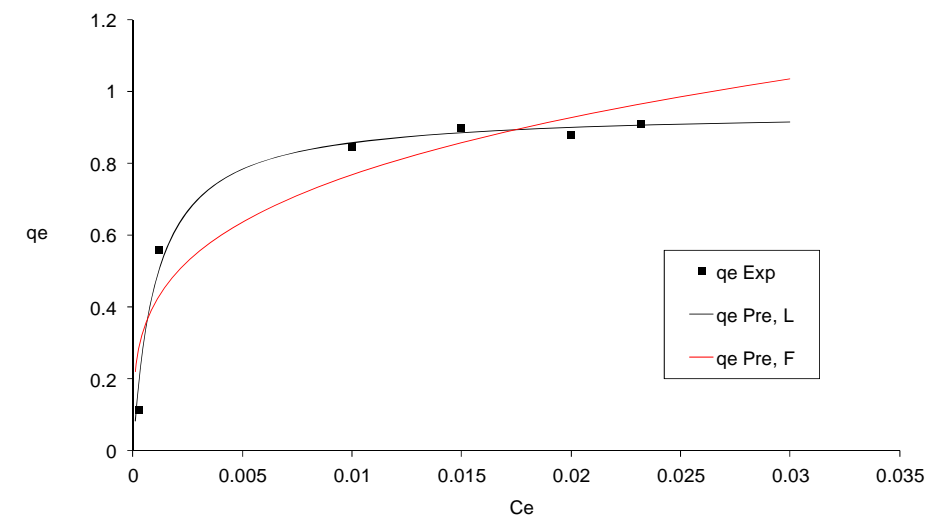

Figure 5: Comparison of Langmuir and Freundlich isotherm.

Table 3: Langmuir and Freundlich constants for the adsorption of bromelain on amine-functionalised SBA-15.

\begin{tabular}{|c|c|c|}
\hline \multicolumn{3}{|c|}{ Freundlich constants } \\
\hline $\mathbf{N}$ & $\mathbf{K}_{\mathbf{F}}$ & $\mathbf{R}^{\mathbf{2}}$ \\
\hline 0.27165 & 2.68522 & 0.8402 \\
\hline \multicolumn{3}{|c|}{ Langmuir constants } \\
\hline $\mathbf{q}_{\max }$ & $\mathbf{K}_{\mathbf{L}}$ & $\mathbf{R}^{\mathbf{2}}$ \\
\hline 0.946281 & 959.381 & 0.9979 \\
\hline
\end{tabular}

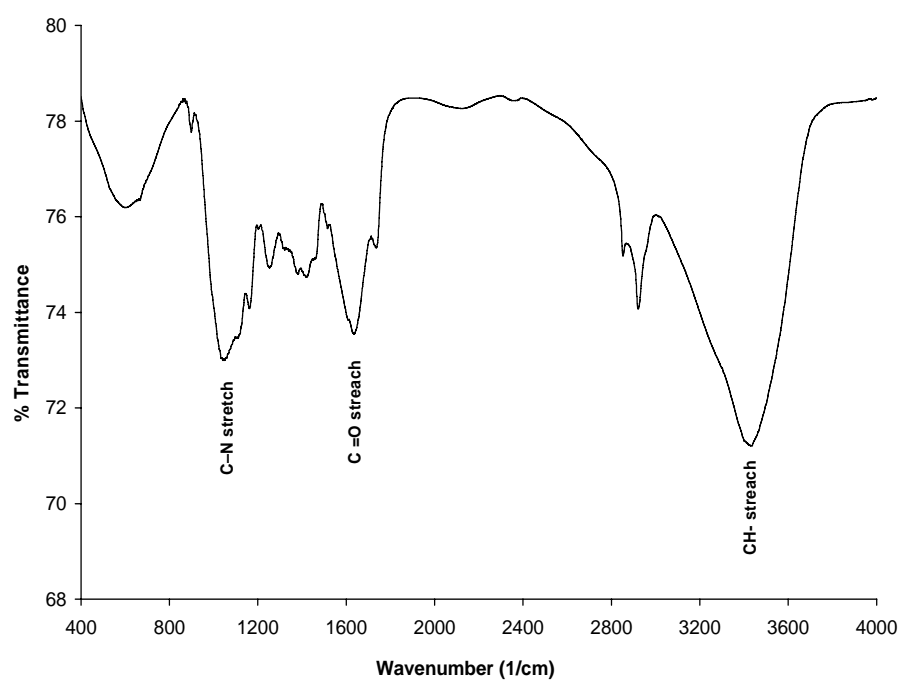

Figure 6: FTIR spectrum of freeze-dried purified bromelain powder.

\section{SDS-PAGE}

Protein adsorbed onto functionalized SBA-15 eluted with Tris- $\mathrm{HCl}$ buffer solution at $\mathrm{pH} 10$ was dialysed for $24 \mathrm{hr}$ and freeze-dried. Sodium dodecyl sulphate-polyacrylamide gel electrophoresis (SDSPAGE) was performed. The extracted enzymes were loaded onto a $4.5 \%$ stacking gel and subjected to electrophoresis on a $12 \%$ separating gel at $100 \mathrm{~V}$ (Genei, Bangalore, India) until the dye stained protein band reached the gel bottom (Ketnawa et al., 2009). SDS-PAGE of purified bromelain is shown in Figure 7. The band obtained was found to have a molecular weight around $33 \mathrm{kDa}$, which is similar to the result reported by Silveira et al. (2009). 


\section{Regeneration of SBA-15}

The results for the regeneration and recycling of the amine-functionalized SBA-15 are shown in Figure 8. The adsorbed amount of bromelain was over
$0.813 \mathrm{mg} / \mathrm{g}$ even after three adsorption cycles, showing that the adsorption capacity of functionalized SBA-15 for bromelain could be almost fully restored. Thus, it can be used as a suitable adsorbent in large scale applications.

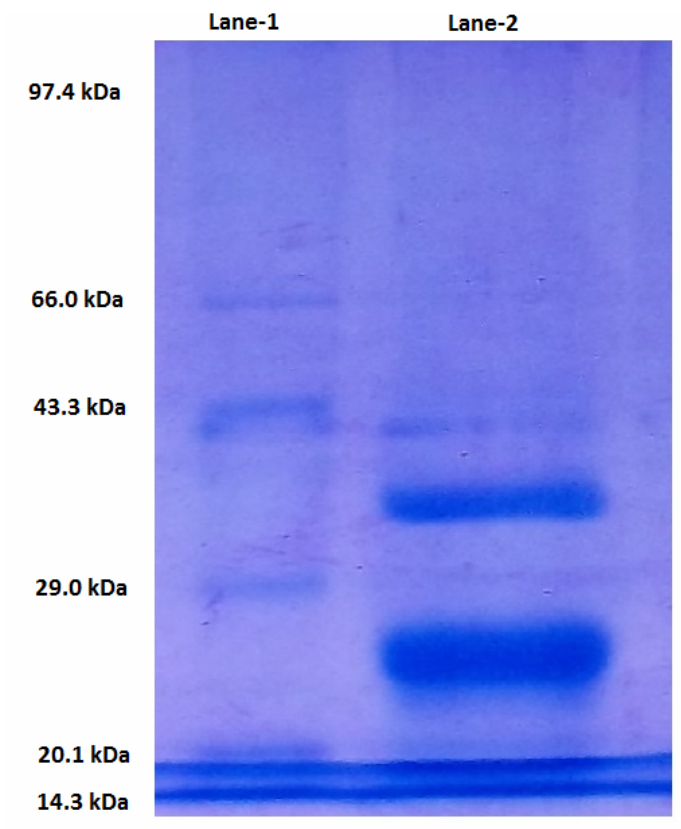

Figure 7: SDS-PAGE electrophoresis of purified bromelain. Lane 1 - molecular weight markers; Lane 2 - Purified bromelain.

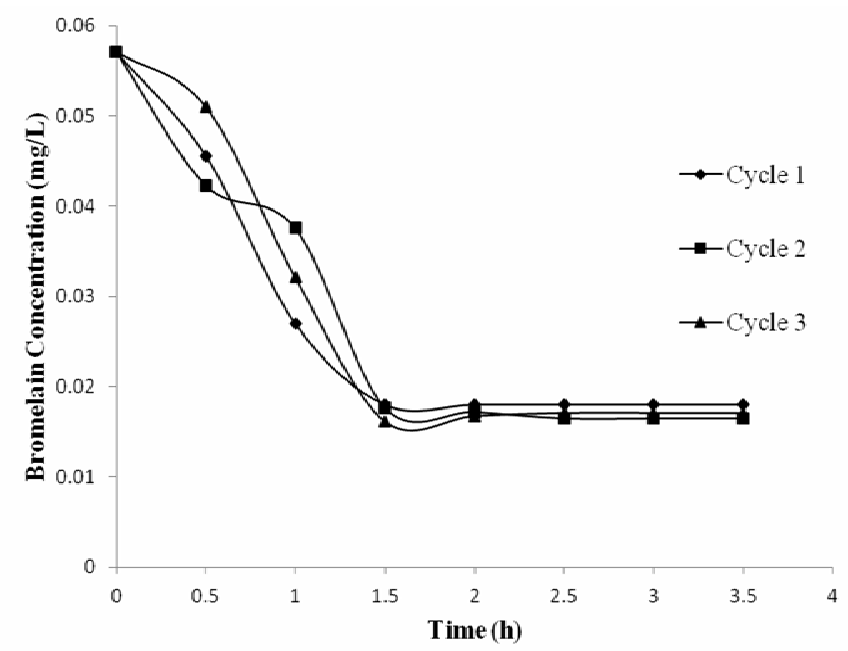

Figure 8: Bromelain adsorption on amine-functionalized SBA-15 


\section{CONCLUSION}

Mesoporous SBA-15 had been successfully synthesised from water glass from sugarcane leaf ash, a low cost silica precursor. It was employed for the recovery of bromelain from pineapple fruit pulp. Bromelain percentage adsorption and purification were found to be $97.89 \%$ and 6.2 -fold, respectively for amine-functionalized SBA-15. The possibility of the regeneration of adsorbent by washing with $\mathrm{pH} 10$ buffer solutions was investigated and found to be efficient. Thus, the recovery of Bromelain from pineapple fruit using mesoporous SBA-15 obtained from a low cost silica precursor appears to be a promising alternate separation method.

\section{REFERENCES}

Aguado, J., Arsuaga, J. M., Arencibia, A., Lindo, M., Gascon, V., Aqueous heavy metals removal by adsorption on amine-functionalized mesoporous silica. J. Hazard Mater., 163, (1), 213-221 (2009).

Bois, L., Bonhomme, A., Ribes, A., Pais, B., Raffin, G. and Tessier, F., Functionalized silica for heavy metal ions adsorption. Colloids Surfaces A: Physicochem. Eng. Aspects, 221, (1-3), 221-230 (2003).

Chen, L., Wang, Y. M. and He, M. Y., Morphological control of mesoporous silica SBA15 synthesized at low temperature without additives. J. Porous Mater., 18, 211-216, 2010.

Devakate, R. V., Patil, V. V., Waje, S. S. and Thorat, B. N., Purification and drying of bromelain. Sep. Purif. Technol., 64, 259-264 (2009).

Ferreira, J. F., Santana, J. C. C., Tambourgi, E. B., The effect of $\mathrm{pH}$ on bromelain partition from Ananas comosus by PEG4000/Phosphate ATPS. Brazilian Archives of Biology and Technol., 54, 125-132 (2011).

Gandhi, S., Sethuraman, S. and Krishnan, U. M., Influence of polyhydric solvents on the catalytic $\&$ adsorption properties of self-oriented mesoporous SBA-15 silica. J. Porous Mater., 18, 329-336 (2011).

Gandhi, S., Venkatesh, S., Sharma, U., Jagannathan., N. R., Sethuraman, S. and Krishnan, U. M., Superparamagnetic nanosystems based on iron oxide nanoparticles \& mesoporous silica: Synthesis \& evaluation of their magnetic, relaxometric and biocompatability properties. J. Mater. Chem., 21, 15698-15707 (2011).

Hale, L. P., Greer, P. K., Trinh, C. T. and James, C. L., Proteinase activity and stability of natural bromelain preparations. International Immunopharmacology, 5, (4), 783-793 (2005).

Halina, M., Ramesha, S., Yarmob, M. A., Kamarudin, R. A., Non-hydrothermal synthesis of mesoporous materials using sodium silicate from coal fly ash. Mater. Chem. Phys., 101, 344-351 (2007).

Hebbar, U. H., Sumana, B., Hemavathi, A. B. and Raghavarao, K. S. M. S., Separation and purification of bromelain by reverse micellar extraction coupled ultrafiltration and comparative studies with other methods. Food Bioprocess Technol., 5, (3) 1010-1018 (2012).

Hwang, D. H., Lee, D., Lee, H., Choe, D., Lee, S. H. and Lee, K., Surface functionalization of SBA-15 particles for ibuprofen delivery. Korean J. Chem. Eng., 27, (4), 1087-1092 (2010).

Jo, C., Kim, K. and Ryoo, R., Syntheses of high quality KIT-6 and SBA-15 mesoporous silicas using low-cost water glass, through rapid quenching of silicate structure in acidic solution. Micropor Mesopor Mater., 124, 45-51 (2009).

Ketnawa, S., Sai-Ut, S., Theppakorn, T., Chaiwut, P., Saroat R., Partitioning of bromelain from pineapple peel (Nang Lae cultv.) by aqueous two phase system. Asian J. Food \& Agro-Industry, 2, (04), 457-468 (2009).

Kokunesoski, M., Gulicovski, M., Matovic, B., Babic, B., Synthesis and characterization of ordered mesoporous Silica. J. Optoelectronics Adv. Mater., 11, 1656-1659 (2009).

Maurer, H. R., Bromelain: Biochemistry, pharmacology and medical use. CMLS, Cell. Mol. Life Sci., 58, 1234-1245 (2001).

Meynen, V., Cool, P., Vansant, E. F., Verified syntheses of mesoporous materials. Micropor Mesopor Mater., 125,170-223 (2009).

Nguyen, T. P. B., Lee, J. W., Shim, W. G. and Moon, H., Synthesis of functionalized SBA-15 with ordered large pore size and its adsorption properties of BSA. Micropor Mesopor Mater., 110, 560-569 (2008).

Park, M., Park, S. S., Selvaraj, M., Zhao, D. and Ha, C. S., Hydrophobic mesoporous materials for immobilization of enzymes. Micropor and Mesopor Mater., 124, 76-83 (2009).

Piccin, J. S., Dotto, G. L., Pinto, L. A. A., Adsorption isotherms and thermochemical data of FD\&C Red $\mathrm{n}^{\circ} 40$ binding by Chitosan. Braz. J. Chem. Eng., 28, (2), 295-304 (2011).

Senthil Kumar, P., Ramakrishnan, K., Dinesh Kirupha, S., Sivanesan, S., Thermodynamic and kinetic studies of cadmium adsorption from aqueous solution onto rice husk. Braz. J. Chem. Eng., 27, (2), 347-355 (2010). 
Silveira, E., Souza-Jr. M. E., Santana, J. C. C., Chaves, A. C., Porto, A. L. F. and Tambourgi, E. B., Expanded bed adsorption of Bromelain (E.C. 3.4.22.33) from Ananas Comosus Crude extract. Braz. J. Chem. Eng., 26, 149-157 (2009).

Song, M. M., Nie, H. L., Zhou, Y. T., Zhu, L. M. and Bao, J. Y., Affinity adsorption of bromelain on reactive Red 120 immobilized magnetic composite particles. Sep. Sci. Technol., 46, 473-482 (2011).

Vijayaraghavan, K., Jegan, J., Palanivelu, K., Velan, M., Removal of nickel(II) ions from aqueous solution using crab shell particles in a packed bed up-flow column. J. Hazard Mater., 113,
223-230 (2004).

Wharton, C. W., The structure and mechanism of stem bromelain. Evaluation of the homogeneity of purified stem bromelain, determination of the molecular weight and kinetic analysis of the bromelain-catalysed hydrolysis of Nbenzyloxycarbonyl-1-phenylalanyl-1-serine methyl ester. Biochem. J., 143, (3), 575-586 (1974).

Zhao, D., Feng, J., Huo, Q., Melosh, N., Fredickson, G. H., Chmelka, B. F., Stucky, G. D., Triblock copolymers syntheses of mesoporous silica with periodic 50 to 300 angstrom pores. Sci., 279, 548552 (1998). 